\title{
FUNGSI PARTAI POLITIK DALAM PENDIDIKAN POLITIK MENURUT UNDANG- UNDANG NOMOR 2 TAHUN 2011 DAN HUKUM ISLAM
}

\author{
Wery Gusmansyah \\ Institut Agama Islam Negeri Bengkulu \\ Jalan Raden Fatah Pagar Dewa Kota Bengkulu \\ Email: werygusmansyah@iainbengkulu.ac.id
}

\begin{abstract}
The form and function of political party in various countries are different from one each in accordance with the system of politics which is applied in the country was. One of the functions of party politics is educate in education politics to the public, will be but the fact that occur at the time of this study politics are carried out by party politics are conducted only on past campaigns ahead of the election, namely the education of voters in terms of elections and the vision of the mission of the parties, regard this indicates that the education politics are conducted directed tho choose the party. In Islam party called Hizbu wich aims for is to help a muslim as an individual in carrying out is obligations to God, amar ma'ruf and forbis the evil, and to realize the leadership for the people of Islam in the entire word. From here seen clearly that, in education must exist an educator who always give instructions, guiding steer, encourage and educate humans to the goodness. And even an educator has the obligation to amar ma'ruf and forbidding evil, which became the principial importance of the main points of religion.
\end{abstract}

Keywords: political education; party; politics.

Abstrak: Bentuk dan fungsi partai politik di berbagai negara berbeda satu sama lain sesuai dengan sistem politik yang diterapkan di negara itu. Salah satu fungsi partai Politik yaitu mendidik dalam pendidikan politik kepada masyarakat, akan tetapi Kenyataan yang terjadi pada saat ini pendidikan politik yang dilakukan oleh partai politik masih sangat kurang. Pendidikan politik yang dilakukan hanya pada masa kampanye menjelang pemilu, yaitu pendidikan pemilih dalam hal pemilu dan visi misi parpol, hal ini mengindikasikan bahwa pendidikan politik yang dilakukan diarahkan untuk memilih partai tersebut. Dalam islam partai disebut hizbu yang bertujuan untuk yaitu membantu seorang muslim sebagai individu dalam melaksanakan kewajibannya terhadap Allah, amar ma'ruf dan nahi munkar, dan untuk mewujudkan kepemimpinan bagi umat Islam di seluruh dunia. Dari sini terlihat jelas bahwa, dalam pendidikan harus ada seorang pendidik yang senantiasa memberikan petunjuk, membimbing mengarahkan, mengajak dan mendidik manusia ke dalam kebaikan. Dan bahkan seorang pendidik mempunyai kewajiban untuk amar ma'ruf dan nahi munkar, yang menjadi pokok penting dari pokok-pokok agama.

Kata Kunci: Pendidikan politik; partai; politik. 
AL-IMARAH: Jurnal Pemerintahan dan Politik Islam Vol. 4, No. 2, 2019

\section{Pendahuluan}

Partai politik adalah sebuah organisasi yang dibentuk untuk memperjuangkan suatu pandangan, keyakinan, dan cita-cita tertentu dari sejumlah orang tentang kehidupan bermasyarakat yang dilakukan dengan caracara perjuangan politik, yakni mengelola kekuasaan agar dapat mempengaruhi prosesproses pembentukan kebijakan publik. ${ }^{1}$ Partai politik merupakan instrumen yang tak terpisahkan dari sistem demokrasi di negara manapun di dunia ini. Partai politik dianggap sebagai perwujudan atau lambang negara modern. Karenanya, hampir semua negara demokrasi maupun komunis, negara maju maupun negara berkembang memiliki partai politik. Namun bentuk dan fungsi partai politik di berbagai negara berbeda satu sama lain sesuai dengan sistem politik yang diterapkan di negara itu.

Partai politik dalam sistem politik demokrasi berfungsi sebagai pemandu berbagai kepentingan, kemudian memperjuangkan melalui proses politik dengan terlebih dahulu berupaya mencari dan mempertahankan kekuasaan melalui pemilu.

Menurut Pasal 11 Undang-Undang Nomor 2 Tahun 2011 tentang perubahan atas Undang-Undang Nomor 2 Tahun 2008 tentang Partai Politik disebutkan fungsi partai politik adalah sebagai berikut:

${ }^{1}$ Efriza, Political Explore (sebuah kajian ilmu Politik), (Bandung: Alfabeta, 2012), h. 218 178 a. pendidikan politik bagi anggota dan masyarakat luas agar menjadi warga negara Indonesia yang sadar akan hak dan kewajibannya dalam kehidupan bermasyarakat, berbangsa, dan bernegara;

b. penciptaan iklim yang kondusif bagi persatuan dan kesatuan bangsa Indonesia untuk kesejahteraan masyarakat;

c. penyerap, penghimpun, dan penyalur aspirasi politik masyarakat dalam merumuskan dan menetapkan kebijakan negara; partisipasi politik warga negara Indonesia; dan

d. rekrutmen politik dalam proses pengisian jabatan politik melalui mekanisme demokrasi dengan memperhatikan kesetaraan dan keadilan gender. ${ }^{2}$

Dalam Pasal 11 huruf a UndangUndang tersebut disebutkan bahwa salah satu fungsi partai politik adalah sebagai sarana pendidikan politik bagi anggota dan masyarakat luas agar menjadi warga negara Indonesia yang sadar akan hak dan kewajibannya dalam kehidupan bermasyarakat, berbangsa, dan bernegara. Pendidikan politik itu sendiri menurut undangundang ini adalah proses pembelajaran dan pemahaman tentang hak, kewajiban, dan tanggung jawab setiap warga negara dalam

${ }^{2}$ Undang-Undang Nomor 2 Tahun 2011 tentang perubahan atas Undang-Undang Nomor 2 Tahun 2008 tentang Partai Politik Pasal 11. 
kehidupan berbangsa dan bernegara. 3

Pendidikan politik juga diartikan sebagai suatu

proses mengajarkan kepada masyarakat mengenai nilai-nilai, norma-norma, serta simbol-simbol politik melalui media berupa sekolah, pemerintah, dan juga partai politik. ${ }^{4}$

Kaum politisi memahami pentingnya pendidikan politik bagi rakyat. Bahkan Plato maupun Aristoteles di zaman kuno, sampai dengan para pakar modern meyakini perlunya anggota masyarakat mendapatkan pendidikan politik, agar bisa ikut aktif berpolitik dan melakukan kegiatan-kegiatan politik melewati lembaga-lembaga politik formal. Lembaga politik dan partai-partai politik itu akan mengatur semua aspirasi politik yang ada di tengah masyarakat. ${ }^{5}$

Kenyataan yang terjadi pada saat ini pendidikan politik yang dilakukan oleh partai politik masih sangat kurang. Pendidikan politik yang dilakukan hanya pada masa kampanye menjelang pemilu, yaitu pendidikan pemilih dalam hal pemilu dan visi misi parpol, hal ini mengindikasikan bahwa pendidikan politik yang dilakukan diarahkan untuk memilih partai tersebut. Kampanye politik dilakukan untuk mengikhtiarkan orang dicalonkan, dipilih, atau dipilih kembali dalam suatu jabatan resmi. Sedangkan, secara garis

\footnotetext{
${ }^{3}$ Undang-Undang Nomor 2 Tahun 2011 tentang perubahan atas Undang-Undang Nomor 2 Tahun 2008 tentang Partai Politik pasal 1 angka 4.

${ }^{4}$ Muhadam Labono dan Teguh Ilham, Partai Politik dan Sistem Pemilihan Umum di Indonesia, (Jakarta: Rajawali Pers, 2017), h. 20

5 Kartini Kartono, Pendidikan Politik, (Bandung: Mandar Maju, 2009), h. 55
}

besar pemilih diartikan sebagai semua pihak yang menjadi tujuan utama para kontestan untuk mereka pengaruhi dan yakinkan melalui kegiatan kampanye politik agar mendukung dan kemudian memberikan suaranya kepada kontestan bersangkutan. ${ }^{6}$

Sangat rumitnya keterkaitan antara masalah kemasyarakatan dengan aspek-aspek politik membuat kebanyakan warganegara semakin sulit memahami dimensi kemasyarakatan dan dimensi politik dari eksistensi dirinya. Juga sulit mengenali hakhak politik dan peranan politiknya. Untuk itu untuk menumbuhkan daya kritis masyarakat maka diperlukanlah penguatan terhadap partai politik sehingga benar-benar mampu dalam menjalankan fungsinya dalam memberikan pendidikan politik kepada masyarakat. ${ }^{7}$

Dalam istilah Islam partai disebut hizbu, yaitu jamaah yang membentuk suatu himpunan atas dasar suatu kepentingan dan saling mendukung. ${ }^{8}$ Sedangkan fungsi partai (hizbu) di dalam Islam di antaranya, yaitu membantu seorang muslim sebagai individu dalam melaksanakan kewajibannya terhadap Allah, amar ma'ruf dan nahi munkar, dan untuk mewujudkan kepemimpinan bagi umat Islam di seluruh dunia. ${ }^{9}$

${ }^{6}$ Efriza, Political Explore..., h. 356
${ }^{7}$ Kartini Kartono, Pendidikan Politik..., h.
${ }^{8}$ Yahyah Ismail, Hubungan Penguasa dan 58

${ }^{8}$ Yahyah Ismail, Hubungan Penguasa dan
am Persfektif Sunnah, (Jakarta: Gema Insani Rakyat dalam Persfe
Press, 1995), h. 64

Press, 1995), h. 64 Y ${ }^{9}$ Yahyah Ismail, Hubungan Penguasa... h. 81 
Menurut Ramlan Surbakti politik tidak hanya dipersepsi sebagai arena konflik dan perebutan kekuasaan, melainkan juga perumusan kebijakan dan pencapaian kepentingan umum. Di situlah, makna politik bisa bersinggungan erat dengan dakwah, dalam pengertian "upaya untuk mengembalikan manusia agar menyembah Allah semata dengan memerintahkan kema'rufan dan mencegah kemungkaran." 10 Firman Allah SWT:

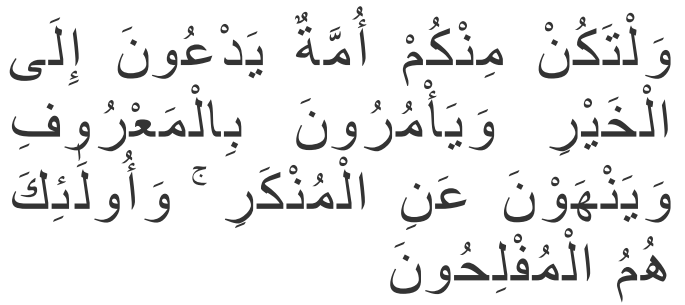

Artinya: "Dan hendaklah ada di antara kamu segolongan umat yang menyeru kepada kebajikan, menyuruh kepada yang ma'ruf dan mencegah dari yang munkar merekalah orang-orang yang beruntung."(Al-Imran: 104) ${ }^{11}$

Ayat ini menjelaskan bahwa hendaklah ada dalam kalangan di antara kalian (muslim) menyediakan diri mengadakan ajakan atau seruan, atau dakwah/mendidik, yang selalu membawa dan mengajak manusia untuk berbuat kebajikan, menyuruh berbuat ma'ruf, yaitu yang patut, pantas dan sopan dan

10 Sapto Waluyo, Kebangkitan Politik Dakwah (Konsep dan Praktik Partai Keadilan Sejahtera di Masa transisi), (Bandung: Harakatuna Publishing, 2005), h. 31

${ }^{11}$ Departemen Agama RI, Al-Qur'an dan Terjemahnya, (Bandung :Cv Diponegoro, 2010), h. 63 180 mencegah, melarang perbuatan munkar, yang di benci dan yang tidak diterima. ${ }^{12}$

Dari sini terlihat jelas bahwa, dalam pendidikan harus ada seorang pendidik yang senantiasa memberikan petunjuk, membimbing mengarahkan, mengajak dan mendidik manusia ke dalam kebaikan. Dan bahkan seorang pendidik mempunyai kewajiban untuk amar ma'ruf dan nahi munkar, yang menjadi pokok penting dari pokok-pokok agama. ${ }^{13}$

Pendidikan politik menjadi modal utama ketahanan umat, dakwah harus tetap berjalan, di bawah tekanan maupun di tengah godan harta dan kekuasaan. ${ }^{14}$

\section{Pembahasan}

\section{A. Fungsi Partai Politik}

Dalam sebuah negara demokrasi, partai politik menyelenggarakan beberapa fungsi, yaitu sebagai berikut:

1. Sebagai Sarana Komunikasi Politik

Dalam hal ini partai politik berfungsi menyatukan aspirasi di dalam masyarakat yang sangat luas dan kompleks kemudian partai politik mengagresasi dan mengartikulasi aspirasi tersebut agar tidak terjadi simpang siur dan saling berbenturan. Setelah itu partai politik merumuskannya menjadi usul

12 Abdulmalik Abdulkarim Amrullah (Hamka), Tafsir al-Qur'an, (Jakarta: Yayasan Nurul Islam, 1981), h. 40

${ }^{13}$ Hasbi ash-Shiddieqy, Tafsir al-Bayyan, Jil. 1, (Jakarta: al-Ma'arif, 1977), h. 311 65

${ }^{14}$ Sapto Waluyo, Kebangkitan Politik..., h. 
kebijakan. Usul kebijakan ini dimasukkan ke dalam program atau platform partai (goal formulation) untuk diperjuangkan atau disampaikan melalui parlemen kepada pemerintah agar dijadikan kebijakan umum (public policy).

Partai politik juga berfungsi memperbincangkan dan menyebarluaskan rencana-rencana dan kebijakan-kebijakan pemerintah. Dengan demikian terjadi arus informasi dan dialog dua arah. Dari atas ke bawah dan dari bawah ke atas. Dalam pada itu partai politik memainkan peran sebagai penghubung antara yang memerintah dan yang diperintah. ${ }^{15}$

2. Sebagai Sarana Sosialisasi Politik

Dalam ilmu politik sosialisasi diartikan sebagai suatu proses yang melaluinya seseorang memperoleh sikap dan orientasi terhadap fenomena politik, yang umumnya berlaku dalam masyarakat di mana ia berada. Ia adalah bagian dari proses yang menentukan sikap politik seseorang. ${ }^{16}$

Sosialisasi politik juga adalah sebagai proses yang melaluinya masyarakat menyampaikan normanorma dan nilai-nilai dari satu generasi ke generasi berikutnya. Di sisi lain fungsi sosialisasi partai adalah upaya

\footnotetext{
${ }^{15}$ Miriam Budiardjo, Dasar-dasar..., h. 406

${ }^{16}$ Miriam Budiardjo, Dasar-dasar..., h. 407
}

menciptakan citra (image) bahwa ia memperjuangkan kepentingan umum. Selain itu ada lagi fungsi partai politik yang lebih tinggi nilainya apabila partai politik dapat menjalankannya, yaitu mendidik anggota-anggotanya menjadi manusia yang sadar akan tanggungjawabnya sebagai warga negara dan menempatkan kepentingan sendiri di bawah kepentingan nasional.

3. Sebagai Sarana Rekrutmen Politik

Fungsi ini berkaitan erat dengan masalah seleksi kepemimpinan, baik kepemimpinan internal maupun kepemimpinan nasional yang lebih luas. Untuk kepentingan internalnya, setiap partai butuh kader-kader yang berkualitas, karena hanya dengan kader yang demikian ia dapat menjadi partai yang mempunyai kesempatan lebih besar untuk mengembangkan diri. Dengan mempunyai kader-kader yang baik, partai politik tidak akan sulit menentukan pemimpinnya sendiri dan mempunyai peluang untuk mengajukan calon untuk masuk ke bursa kepemimpinan nasional. ${ }^{17}$

Selain untuk tingkatan seperti itu partai politik juga berkepentingan memperluas atau memperbanyak keanggotaanya. Maka ia pun berusaha menarik sebanyak-banyaknya orang untuk menjadi anggotanya. Dengan

${ }^{17}$ Miriam Budiardjo, Dasar-dasar..., h. 408 
didirikannya organisasi-organisasi massa (sebagai onderbouw) yang melibatkan golongan-golongan buruh, petani, pemuda, mahasiswa, wanita dan sebagainya, kesempatan untuk berpartisipasi diperluas.

4. Sebagai Sarana Pengatur Konflik

$$
\text { Partai politik berfungsi }
$$

menjadi penghubung psikologis dan organisasional antara warga negara dengan pemerintahnya. Selain itu partai melakukan konsolidasi dan artikulasi tuntutan-tuntutan yang beragam yang berkembang di berbagai kelompok masyarakat. Partai juga merekrut orang-orang untuk diikutsertakan dalam kontes pemilihan wakil-wakil rakyat dan menemukan orang-orang yang cakap untuk menduduki posisi-posisi eksekutif. ${ }^{18}$

Selain fungsi-fungsi di atas berikut ini ada beberapa fungsi partai politik menurut para ilmuan, yaitu sebagai berikut:

a. Menurut Almond ada delapan fungsi partai politik, yaitu:

Tiga fungsi yang pertama tidak secara langsung terlibat dalam pembuatan dan pelaksanaan kebijakan pemerintahan (public policy), tetapi sangat penting dalam menentukan cara bekerjanya sistem politik

1. Sosialisasi Politik

\footnotetext{
${ }^{18}$ Miriam Budiardjo, Dasar-dasar..., h. 405
}

Merupanakan fungsi pengembangan dan memperkuat sikap-sikap politik di kalangan penduduk umunya, atau bagianbagian dari penduduk, atau melatih rakyat untuk menjalankan peranperan politik, administratif, yudisial tertentu.

2. Rekrutmen Politik

Merupakan fungsi penyeleksian rakyat untuk kegiatan politik dan jabatan pemerintahan melalui penampilan dalam media komunikasi, menjadi anggota organisasi, mencalonkan diri untuk jabatan tertentu, pendidikan, dan ujian.

3. Komunikasi Politik

$$
\text { Merupakan jalan }
$$
mengalirnya informasi melalui masyarakat dan melalui struktur yang ada dalam sistem politik.

Lima politik lainnya terkait dengan pembuatan dan pelaksanaan kebijakan dalam setiap sistem politik.

1. Artikulasi Kepentingan

Sebelum kebijakankebijakan itu dapat ditentukan, individu-individu dan kelompokkelompok dalam masyarakat menentukan apa yang menjadi kepentingan mereka, yaitu apa yang mereka ingin dapatkan dari 
Wery Gusmansyah: Fungsi Partai Politik Dalam Pendidikan Politik Menurut Undang-Undang Nomor 2 Tahun 2011 Dan Hukum Islam

politik (artikulasi kepentingan).

Partai politik melaksanakan fungsi

artikulasi kepentingan ini dengan

membuat dan menyampaikan

tuntutan-tuntutan

kepada

pemerintah.

2. Agregasi Kepentingan

Kepentingan dan tuntutantuntutan masyarakat itu kemudian digabungkan menjadi alternatifalternatif kebijakan (agregasi kepentingan). Fungsi ini dijalankan partai politik dengan menggabungkan tuntutan-tuntutan dari kelompok-kelompok masyarakat yang berbeda menjadi alternatif-alternatif kebijakan pemerintahan.

3. Pembuatan Kebijakan

$$
\text { Selajutnya alternatif- }
$$

alternatif itu dipertimbangkan dan ditentukan pilihan (pembuatan kebijakan). Fungsi ini dijalankan apabila partai menjadi pemerintah yang menguasai mayoritas kursi di parlemen, atau yang calon presidennya memenagkan pemilihan umum. Jika menjadi partai oposisi, ia mengkritik dan mengusulkan alternatif kebijakan.

4. Penerapan Kebijakan

Proses $\begin{aligned} & \text { selanjut adalah } \\ & \text { pelaksanaan atau penerapan } \\ & \text { kebijakan. }\end{aligned}$

5. Penghakiman Kebijakan

Bila kebijakan itu ditentang atau diselewengkan maka harus ada proses penghakiman (adjudication).

Terhadap dua fungsi yang akhir ini, partai politik hanya melakukan pengawasan sebagai bagian dari kontrol sosial. Penerapan kebijakan dilaksanakan oleh pejabat publik (yang mungkin saja orang partai) yang bekerja berdasarkan prinsip amanah serta clear and good government. Sementara fungsi kehakiman adalah fungsi lembaga yudisial yang independen, tidak boleh dicampuri oleh eksekutif, legislatif, maupun masyarakat, termasuk partai politik. $^{19}$

Menurut Nico Harjanto fungsi-fungsi utama partai politik, yaitu:

1. Untuk menyerap dan menyalurkan aspirasi dan kepentingan rakyat;

2. Melakukan pendidikan politik kepada masyarakat tentang hak dan kewajiban warga negara dalam kehidupan bernegara;

3. Melakukan rekrutmen politik secara demokratis sesuai dengan peraturan perundangan yang 
berlaku untuk mengisi jabatanjabatan publik di semua tingkatan pemerintahan;

4. Memformulasi dan menetapakan kebijakan umum melalui institusi legislatif dan eksekutif di semua tingkatan pemerintahan;

5. Melakukan pengawasan atas pelaksanaan kebijakan publik melalui para kadernya di lembaga legislatif;

6. Menjadi penengah anatara kepentingan/aspirasi rakyat dengan pemerintah beserta kebijakankebijakannya; dan

7. Menjadi alat pengontrol kepentingan pribadi politisi yang duduk sebagai wakil rakyat maupun pejabat publik.

Sementara Menurut Maurice Duverger ada enam fungsi partai politik, yaitu:

1. Pendidikan politik (political education);

2. Seleksi politik (political selection);

3. Penghimpunan kegiatan politik (political aggregation);

4. Saluran pernyataan kepentingan (interest articulation);

5. Pengawasan dan pengendalian politik (political contril); dan

6. Komunikasi politik (political communication).

\section{B. Pendidikan Politik}

Pendidikan politik disebut juga sebagai political forming atau politische bildung. Disebut "forming" karena terkandung intensi untuk membentuk insan politik yang menyadari kedudukan politiknya di tengah masyarakat. Dan disebut "bildung" karena istilah tersebut menyangkut aktivitas membntuk diri sendiri, dengan kesadaran penuh dan tanggungjawab sendiri menjadi insan politik. $^{20}$

Dalam Pasal 1 ayat 4 UndangUndang Nomor 2 Tahun 2011 tentang perubahan atas Undang-Undang Nomor 2 Tahun 2008 tentang Partai Politik pendidikan Politik adalah proses pembelajaran dan pemahaman tentang hak, kewajiban, dan tanggung jawab setiap warga negara dalam kehidupan berbangsa dan bernegara. ${ }^{21}$

Jika dikaitkan dengan partai politik, pendidikan politik bisa diartikan sebagai usaha sadar dan tersistematis dalam mentransformasikan segala sesuatu yang berkenaan dengan perjuangan partai poltik tersebut kepada massanya agar mereka sadar akan peran dan fungsi, serta (Bandung: Mandar Maju, 2009), h. 63

${ }^{21}$ Undang-Undang Nomor 2 Tahun 2011 tentang perubahan atas Undang-Undang Nomor 2 Tahun 2008 tentang Partai Politik Pasal 1 Ayat 4. 
Wery Gusmansyah: Fungsi Partai Politik Dalam Pendidikan Politik Menurut Undang-Undang Nomor 2 Tahun 2011 Dan Hukum Islam

hak dan kewajibannya sebagai warga negara. $^{22}$

Dalam Pasal 1 ayat 1 UndangUndang Nomor 2 Tahun 2011 tentang perubahan atas Undang-Undang Nomor 2 Tahun 2008 tentang Partai Politik Partai Politik adalah organisasi yang bersifat nasional yang dibentuk oleh sekelompok warga negara Indonesia secara sukarela atas dasar kesamaan kehendak dan cita-cita untuk memperjuangkan dan membela kepentingan politik anggota, masyarakat, bangsa dan negara, serta memelihara keutuhan Negara Kesatuan Republik Indonesia Tahun $1945 .^{23}$

Dalam pasal 11 huruf a UndangUndang tersebut menyebutkan bahwa salah satu fungsi partai politik adalah pendidikan politik bagi anggota dan masyarakat luas agar menjadi warga negara Indonesia yang sadar akan hak dan kewajibannya dalam kehidupan bermasyarakat, berbangsa, dan bernegara. $^{24}$

Selain itu kewajiban partai politik dalam pendidikan politik juga disebutkan dalam Pasal 13 huruf e Undang-Undang Nomor 2 Tahun 2008 Tentang Partai Politik yang berbunyi: Partai politik

22 https://www.dicto.id/t/apa-yangdimaksud-dengan-politik-pendidikan/11455, diakses pada tanggal 15 Juli 2018 pukul 08:15 WIB.

${ }^{23}$ Undang-Undang Nomor 2 Tahun 2011 tentang perubahan atas Undang-Undang Nomor 2 Tahun 2008 tentang Partai Politik Pasal 1 Ayat 1.

${ }^{24}$ Undang-Undang Nomor 2 Tahun 2011 tentang perubahan atas Undang-Undang Nomor 2 Tahun 2008 tentang Partai Politik Pasal 11 huruf a. berkwajiban melakukan pendidikan politik dan menyalurkan aspirasi politik anggotanya. Pasal 31 ayat 1 UndangUndang Nomor 2 Tahun 2008 Tentang Partai Politik yang berbunyi: Partai Politik melakukan pendidikan politik bagi masyarakat sesuai dengan ruang lingkup tanggung jawabnya dengan memperhatikan keadilan dan kesetaraan gender dengan tujuan antara lain:

a. meningkatkan kesadaran hak dan kewajiban masyarakat dalam kehidupan bermasyarakat, berbangsa, dan bernegara;

b. meningkatkan partisipasi politik dan inisiatif masyarakat dalam kehidupan bermasyarakat, berbangsa, dan bernegara; dan

c. meningkatkan kemandirian, kedewasaan, dan membangun karakter bangsa dalam rangka memelihara persatuan dan kesatuan bangsa.

Selain aturan yang terdapat dalam Undang-Undang yang secara khusus mengatur tentang Partai Politik landasan pokok yang dipakai dalam melaksanakan pendidikan politik di Indonesia, yaitu sebagai berikut:

a. Pancasila

Pancasila digunakan sebagai landasan pokok dalam pelaksanaan pendidikan politik dikarenakan pancasila merupakan falsafah, pandangan hidup, sekaligus dasar 
negara Indonesia, yang memberikan identitas kepada bangsa Indonesia. Identitas inilah yang sudah seharusnya diselami oleh bangsa Indonesia, utamanya generasi muda agar dapat memahami secara benar karakter dirinya, potensi keunggulan dan kekurangan yang dimiliki, sehingga mampu mengatasi persoalan hidup dan tantangan global.

b. Undang-Undang 1945

$$
\text { Undang-Undang }
$$

merupakan landasan konstitusional, digunakan sebagai landasan pendidikan politik dengan harapan agar bangsa Indonesia, khususnya generasi muda dapat memahami hak dan kewajibannya secara baik serta mampu menjadi warga negara yang sadar dan taat hukum. Melalui tangan-tangan generasi muda yang bersih dan jujur, diharapkan dapat dibangun negara Indonesia yang merdeka, bersatu, berdaulat, maju, adil dan makmur.

c. Sumpah pemuda 1928

Sumpah pemuda 1928 menjadi landasan politik dikarenakan semangat persaudaraan, kekeluargaan, persatuan dan semangat pantang menyerah yang telah dibangun oleh para pemuda 1928 dapat menjadi inspirasi bagi generasi muda Indonesia bahwa dengan semangat kebersamaan dan persaudaraan akan dapat diwujudkan
Indonesia yang jaya gilang-gemilang pada milennium ketiga.

d. Negara Kesatuan Republik Indonesia (NKRI)

Negara Kesatuan Republik Indonesia (NKRI) merupakan harga mati bagi kehidupan berbangsa dan bernegara Indonesia, dikarenakan bentuk kenegaraan inilah yang terbukti mampu mempersatukan bangsa Indonesia di saat menghadapi krisis persatuan dan kesatuan.

e. Bhinneka Tunggal Ika

Bhinneka Tunggal Ika merupakan prinsip dan asas berbangsa dan bernegara Indonesia yang tidak bisa diabaikan, dikarenakan dalam realitanya Indonesia memiliki kemajemukan sosial budaya serta kemajemukan vertikal horizontal. Kemajemukan ini harus dipelihara dan dijadikan sebagai kekayaan sosial budaya Indonesia, sehingga bangsa Indonesia tidak akan kehabisan bahan kreasi dalam mengembangkan modal berkehidupan bermasyarakat, berbangsa, dan bernegara. ${ }^{25}$

Sementara dalam Pasal 34 ayat $3 b$ Undang-Undang Nomor 2 Tahun 2011 tentang perubahan atas Undang-Undang Nomor 2 Tahun 2008 tentang Partai Politik

25 Eko Handoyo dan Puji Lestari, Pendidikan Politik, (Yogyakarta: Pohon Cahaya, 2017), h. 14 
menjelaskan bahwa pendidikan politik berkaitan dengan:

a. Pendalaman mengenai empat pilar berbangsa dan bernegara yaitu Pancasila, UUD 1945, Bhineka Tungga Ika, dan Negara Kesatuan Republik Indonesia;

b. Pemahaman mengenai hak dan kewajiban warga negara Indonesia dalam membanguan etika dan budaya politik; dan

c. Pengkaderan anggota partai politik secara berjenjang dan berkelanjutan. ${ }^{26}$

Dari uraian di atas penulis menyimpulkan bahwa kesadaran politik warga negara adalah kesadaran akan hak dan kewajibannya sebagai warga negara terhadap negara dan permasalahannya. Oleh karena itu tinggi rendahnya kesadaran politik warga negara akan mempengaruhi tinggi rendahnya partisipasi politik warga negara tersebut. Hal ini juga berarti bahwa tinggi rendahnya tingkat partisipasi politik juga dipengaruhi oleh kinerja partai politik sebagai pelaksana pendidikan politik.

Hal ini sesuai dengan tujuan partai politik yang disebutkan dalam Pasal 10 Undang-Undang No. 2 tahun 2008 tentang Partai Politik tujuan khusus partai politik adalah:
a. meningkatkan partisipasi politik anggota dan masyarakat dalam rangka

penyelenggaraan kegiatan politik dan pemerintahan;

b. memperjuangkan cita-cita partai politik dalam kehidupan bermasyarakat, berbangsa dan bernegara;

c. membangun etika dan budaya politik dalam kehidupan bermasyarakat, berbangsa dan bernegara. ${ }^{27}$

\section{Pendidikan Politik dalam Hukum Islam}

Pendidikan secara umum didefinisikan sebagai usaha yang sadar, terarah dan disertai dengan pemahaman yang baik untuk menciptakan perubahanperubahan yang diharapkan baik sikap maupun prilaku seseorang atau kelompok melalui upaya pengajaran dan pelatihan.

Adapun relasinya dengan dunia politik, pendidikan politik dimaksudkan sebagai upaya membangun dan menumbuhkan keyakinan dan nilai dalam rangka membentuk kepribadian politik yang dikendaki melalui terbentuknya orientasi dan sensivitas politik para anggota sehingga menjadi partisipan aktif dalam kehidupan politik keseharian mereka.

Istilah pendidikan politik di dalam Islam disebut dengan Tarbiyah siyasiyah. Tarbiyah siyasiyah didefinisikan sebagai upaya membangun dan menumbuhkan keyakinan dan nilai dalam rangka membentuk kepribadian politik yang
${ }^{26}$ Undang-Undang Nomor 2 Tahun 2011 tentang perubahan atas Undang-Undang Nomor 2 Tahun 2008 tentang Partai Politik Pasal 34 ayat 3b.
${ }^{27}$ Undang-Undang Nomor 2 Tahun 2008 tentang Partai Politik Pasal 10. 
dikehendaki melalui terbentuknya orientasi dan sensevitas politik para anggota sehingga menjadi partisipan politik aktif dalam kehidupan politik keseharian mereka. $^{28}$

Pendidikan politik adalah salah satu dimensi fundamental diantara berbagai dimensi lain pendidikan. Pendidikan politik pada dasarnya merupakan kebutuhan darurat dalam menyiapkan kaum Muslimin untuk dapat mengemban tanggung jawab serta menunaikan hak dan kewajibannya. Allah SWT. Berfirman:

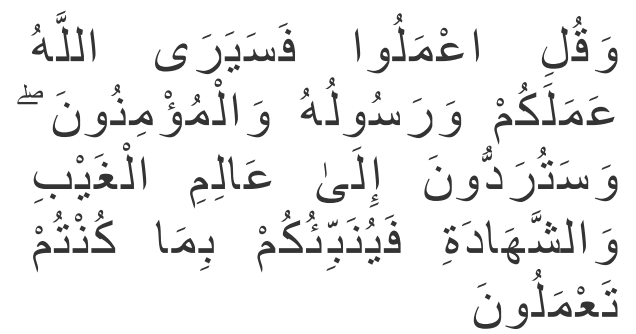

Artinya, : "Dan Katakanlah: "Bekerjalah kamu, Maka Allah dan rasulNya serta orang-orang mukmin akan melihat pekerjaanmu itu, dian kamu akan dikembalikan kepada (Allah) yang mengetahui akan yang ghaib dan yang nyata, lalu diberitakanNya kepada kamu apa yang Telah kamu kerjakan." (QS. AtTaubah: 105) ${ }^{29}$

Adapun tujuan yang hendak dicapai melalui tarbiyah siyasiyah, yaitu:

a. Munculnya kesadaran politik (wa'yu siyan kemudian msi), yaitu memiliki

${ }^{28}$ https://pejuangcahaya.wordpress.com/201 4/11/01/ulasan-mengenai-tarbiyah-siyasiyah. diakses pada tanggal 15 Juli 2018 pukul 08:30 WIB.

${ }^{29}$ Departemen Agama RI, Al-Qur'an dan Terjemahnya, (Bandung :Cv Diponegoro, 2010), h. 203 188 pengetahuan politik yang integral, mampu membuat analisis yang matang dan kemudian menempatkan dirinya dalam arus perubahan.

b. Terbentuknya kepribadian politik (dzat siyasiyah), yang mencakup tertanamnya keyakinan dan nilai politik, munsulnya orientasi, sensivitas dan loyalitas politik (huwaiyyah siyasiyah) yang kuat serta memiliki pengetahuan, informasi dan konsepsi politik (nazharat siyasiyah) secara utuh.

c. Munculnya partisipasi politik yang aktif (musyarakah siyasiyah), yakni keinginan kuat seseorang untuk berpartisipasi secara aktif dalam keseluruhan proses dan aktivitas politik baik secara individual (memberikan suara dan pendidikan politik) maupun kelembagaan (terlibat dalam organisasi dan partai politik). ${ }^{30}$

Allah SWT berfirman:

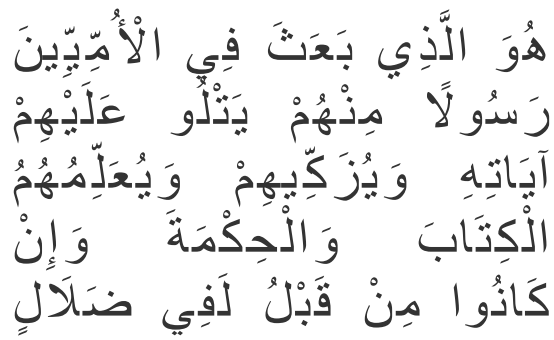

Artinya: "Dia-lah yang mengutus kepada kaum yang buta huruf seorang Rasul di antara mereka, yang membacakan

${ }^{30}$ Ahmeddzakarin.blogspot.com/2010/08/ba b-i-pendidikan-politik-tarbiyah.html. diakses pada tanggal 15 Juli 2018 pukul 08:22 WIB. 
Wery Gusmansyah: Fungsi Partai Politik Dalam Pendidikan Politik Menurut Undang-Undang Nomor 2 Tahun 2011 Dan Hukum Islam

\begin{abstract}
ayat-ayat-Nya kepada mereka, mensucikan mereka dan mengajarkan mereka Kitab dan hikmah (As Sunnah). dan Sesungguhnya mereka sebelumnya benarbenar dalam kesesatan yang nyata." (QS. Jum'ah: 2) ${ }^{31}$
\end{abstract}

Adapun tujuan yang hendak dicapai sebagai output pendidikan politik Islam:

a. Aspek Kognitif

Kaum Muslimin memiliki pemahaman epistomologis tentang sistem politik dalam Islam yang merupakan bagian dari pemahaman kita tentang syumuliyatul Islam (integralitas Islam). Asy Syahid Imam Hasan Al Banna dalam 20 prinsip Al Fahmu menjelaskan: "Islam adalah sistem yang syamil (menyeluruh) mencakup seluruh aspek kehidupan. Ia adalah negara dan tanah air, pemerintahan dan umat, moral dan kekuatan, kasih sayang dan keadilan, peradaban dan undang, ilmu pengetahuan dan hukum, materi dan kekayaan alam, penghasilan dan kekayaan, jihad dan dakwah, serta pasukan dan pemikiran.

Sebagaimana ia juga aqidah yang murni dan ibadah yang benar, tidak kurang tidak lebih." Pendidikan politik ini tidak hanya meliputi transformasi aspek kognitif namun juga sublimasi (shibghah) nilai-nilai afektif seperti yang dijelaskan prinsip $\mathrm{Al}$ Fahmu dalam Risalah Ta'lim. Proses pendidikan politik ini diharapkan mampu menanamkan pemahaman shahih bahwa sistem politik Islam bersifat khas dan berbeda karena dibangun dari fondasi tauhid yang kokoh. Penanaman-pemahaman sistem politik Islam yang benar merupakan bagian dari rangkaian konstruksi keyakinan dan nilai yang ditanamkan bahwa Islam adalah solusi (Islam huwal hal). Abu Hayyan menjelaskan bahwa kekhasan sistem politik terletak kepada dua hal: pertama, menegakkan hukum (Islam) secara benar dan adil. Kedua, memakmurkan (isti'mar) bumi (menegasikan cara pandang dan perilaku

eksploitatif). Isti'mar mengandung makna memanfaatkan sumber daya alam bagi kepentingan kesejahteraan umat manusia namun dengan memperhatikan aspek konservasi. Pada aspek ini pula, kaum Muslimin secara konseptual dapat melakukan perbandingan (comparative study) antara Islam dengan sistem-sistem politik lainnya.

b. Aspek Implementatif

Output terakhir dalam proses pendidikan politik (tarbiyah siyasah) 
ini adalah lahirnya kesadaran kaum Muslimin berupa terbentuknya orientasi dan partisipasi politik yang tidak tergoyahkan dari pemahaman keyakinan yang terbangun. Orientasi politik ini terwujudkan dalam afiliasi ideologi yang jelas (Islam) dan kerinduan yang kuat untuk terlibat dalam amal Islami (organisasi maupun partai politik) yang bertujuan merealisasikan cita-cita politik Islam. Pendidikan politik dalam konteks ini bermaksud-mengutip Anis Mattamerubah kondisi kaum Muslimin dari statusnya yang afiliatif menjadi partisipatif dan kontributif. Allah SWT berfirman:

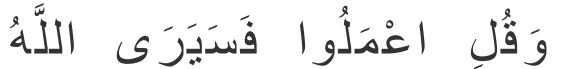

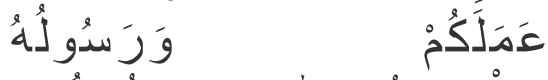

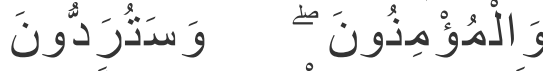

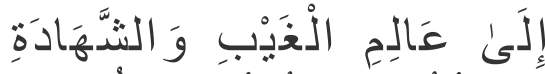

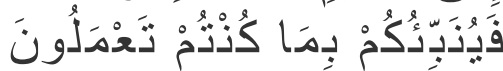

Artinya: “Dan katakanlah,'Beramallah kalian, maka Allah dan Rasul-Nya serta orang-orang mukmin akan melihat amal kalian itu, dan kalian akan dikembalikan kepada Allah yang mengetahui akan yang gaib dan yang nyata, lalu diberitakan-Nya kepada kalian apa yang telah kalian amalkan." (QS. At-Taubah: 105)

Dari uraian di atas penulis menyimpulkan bahwa pendidikan politik (tarbiyah siyasiyah) adalah upaya membangun kesadaran umat muslim tentang hak dan kewajibannya sehingga timbul keinginan untuk berpartisipasi secara aktif dalam keseluruhan proses dan aktivitas politik.

\section{Penutup}

Dalam sebuah negara demokrasi, partai politik menyelenggarakan beberapa fungsi, yaitu: Sebagai Sarana Komunikasi Politik, Sebagai Sarana Sosialisasi Politik, Sebagai Sarana Rekrutmen Kesadaran politik warga negara adalah kesadaran akan hak dan kewajibannya sebagai warga negara terhadap negara dan permasalahannya. Oleh karena itu tinggi rendahnya kesadaran politik warga negara akan mempengaruhi tinggi rendahnya partisipasi politik warga negara tersebut. Hal ini juga berarti bahwa tinggi rendahnya tingkat partisipasi politik juga dipengaruhi oleh kinerja partai politik sebagai pelaksana pendidikan politik. Hal ini sesuai dengan tujuan partai politik yang disebutkan dalam Pasal 10 Undang-Undang No. 2 tahun 2008 tentang Partai Politik tujuan khusus partai politik.

Istilah pendidikan politik di dalam Islam disebut dengan Tarbiyah siyasiyah. Tarbiyah siyasiyah didefinisikan sebagai upaya membangun dan menumbuhkan keyakinan dan nilai dalam rangka membentuk kepribadian politik yang dikehendaki melalui terbentuknya orientasi dan sensevitas politik para anggota sehingga menjadi partisipan politik aktif dalam kehidupan politik keseharian mereka. 
bahwa pendidikan politik (tarbiyah siyasiyah) adalah upaya membangun kesadaran umat muslim tentang hak dan kewajibannya sehingga timbul keinginan untuk berpartisipasi secara aktif dalam keseluruhan proses dan aktivitas politik.

\section{Pustaka Acuan}

Abdulmalik Abdulkarim Amrullah (Hamka), Tafsir al-Qur'an, Jakarta: Yayasan Nurul Islam, 1981

Departemen Agama RI, Al-Qur'an dan Terjemahnya, Bandung: $\quad \mathrm{Cv}$ Diponegoro, 2010

Departemen Agama RI, Al-Qur'an dan Terjemahnya, Bandung $: \mathrm{Cv}$ Diponegoro, 2010

Efriza, Political Explore (sebuah kajian ilmu Politik), Bandung: Alfabeta, 2012

Eko Handoyo dan Puji Lestari, Pendidikan Politik, Yogyakarta: Pohon Cahaya, 2017

Hasbi ash-Shiddieqy, Tafsir al-Bayyan, Jil. 1, Jakarta: al-Ma'arif, 1977

Kartini Kartono, Pendidikan Politik, Bandung: Mandar Maju, 2009

Muhadam Labono dan Teguh Ilham, Partai Politik dan Sistem Pemilihan Umum di Indonesia, Jakarta: Rajawali Pers, 2017

Sapto Waluyo, Kebangkitan Politik Dakwah (Konsep dan Praktik Partai Keadilan Sejahtera di Masa transisi), Bandung: Harakatuna Publishing, 2005

Undang-Undang Nomor 2 Tahun 2011 tentang perubahan atas Undang-Undang Nomor 2 Tahun 2008 tentang Partai Politik

Yahyah Ismail, Hubungan Penguasa dan Rakyat dalam Persfektif Sunnah, Jakarta: Gema Insani Press, 1995 